\title{
ANALISIS YURIDIS NIKAH BEDA AGAMA MENURUT HUKUM ISLAM DI INDONESIA ${ }^{1}$
}

\author{
Islamiyati \\ Fakultas Hukum Universitas Diponegoro Semarang \\ J1. Prof. Sudharto, SH No.1 Tembalang Semarang \\ Email: islamiyati@yahoo.co.id
}

\begin{abstract}
Interfaith marriage is a marriage that a couple who has a different religion, and one non-Islamic religion. According to the juridical rules in Indonesia, namely the Marriage Law No. 1/1974 Article 2 Paragraph (1) and Article 8 Letter (f), KHI Presidential Instruction No. 1/1991 Article 40 point (c), 44 and 118, and Article 44, and Islamic law stipulates that interfaith marriage in all its forms haram unless there is equalization of faith for the couple. The legal consequence of marriage becomes void if there are parties who apply for annulment to the judge, and the judge's decision has had permanent legalforce.
\end{abstract}

Keywords: Interfaith Marriage; Islamic law in Indonesia.

\begin{abstract}
Abstrak
Nikah beda agama adalah pernikahan yang dilakukan oleh pasangan yang beda agamanya, dan salah satunya beragama non Islam. Menurut aturan yuridis di Indonesia yakni UU Perkawinan No. 1/1974 Pasal 2 Ayat (1) dan Pasal 8 Huruf(f), KHI Inpres No. 1/1991 Pasal 40 Poin (c), 44 dan 118, menetapkan bahwa perkawinan beda agama dalam segala bentuknya haram, kecuali terjadi penyamaan keimanan bagi pasangan. Akibat hukumnya adalah perkawinan menjadi batal apabila ada pihak yang mengajukan permohonan pembatalan pernikahan kepada hakim, dan keputusan hakim telah mempunyai kekuatan hukum tetap.
\end{abstract}

Kata Kunci: Nikah Beda Agam; Hukum Islam di Indonesia.

\section{A. Pendahuluan}

1. Latar Belakang Permasalahan

Nikah beda agama merupakan pernikahan yang dilakukan oleh pasangan yang berbeda agama atau keyakinannya. Mereka melakukan pernikahan tersebut karena didasari cinta yang kemudian bersepakat untuk hidup bersama dalam sebuah keluarga. Namun, nikah beda agama menurut hukum perkawinan di Indonesia tidak diperbolehkan, karena masing-masing agama mengajarkan supaya pernikahan dilaksanakan oleh pasangan yang sama keimanannya. Jika tidak demikian, maka perkawinan tersebut tidak sah dan dapat dibatalkan. $^{2}$

Menurut UU Perkawinan No. 1 Tahun
1974 Pasal 2 Ayat (1), menjelaskan bahwa suatu perkawinan dapat dikatakan perkawinan yang sah, jika perkawinan itu dilakukan menurut hukum masing-masing agama dan kepercayaannya itu. Berarti tidak ada perkawinan yang sah, kecuali perkawinan yang sesuai dengan hukum masing-masing agama para pemeluknya. Peran negara dalam perkawinan adalah menguatkan perkawinan yang sudah disahkan oleh hukum agama, melalui pencatatan perkawinan supaya pelakunya mendapatkan perlindungan hukum.

Pada jaman sekarang banyak terjadi pernikahan beda agama, namun tidak sesuai dengan ketentuan hukum agama, karena terjadi perbedaan penafsiran Pasal 2 Ayat (1)

1. Artikel ini merupakan hasil penelitian.

2. Departemen Agama RI, 2004, Undang-Undang Nomor 1 Tahun 1974 Tentang Perkawinan dan Peraturan Pemerintah Nomor 9, Tahun 1975, Serta Kompilasi Hukum Islam di Indonesia, Jakarta, Departemen Agama R.I. Derektorat Jenderal Bimbingan Masyarakat Islam dan Penyelenggaraan Haji, hlm. 32 
UU Perkawinan tentang persepsi sahnya perkawinan. Banyak warga negara yang beradaptasi negatif terhadap Pasal 2 Ayat (1) UU Perkawinan dengan cara melakukan penyelundupan atau mengenyampingkan hukum nikah beda agama. ${ }^{3}$ Ada dua cara penyelundupan hukum pada kasus nikah beda agama, yakni: ${ }^{4}$

a. Mengenyampingkan hukum nasional, misalnya; perkawinan di luar negeri dan melangsungkan perkawinan secara adat.

b. Mengenyampingkan hukum agama, misalnya; menikah dua kali dan berpindah agama sementara pada saat perkawinan dilangsungkan, kemudian kembali pada agama semula setelah perkawinan dilangsungkan.

Maraknya penyelundupan hukum perkawinan, menjadikan hukum perkawinan telah kehilangan kewibawaan hukum dan menggambarkan bahwa hukum perkawinan tidak sesuai dengan kebutuhan dan keinginan masyarakat. Menurut pelaku penyelundupan hukum, menjelaskan bahwa pengaturan Pasal 2 Ayat (1) UU Perkawinan tidak memperhatikan penyelamatan dan perlindungan hukum bagi pelaku pernikahan beda agama, sehingga hak konstitusional seluruh warga negara pada umumnya dan pelaku nikah beda agama ${ }^{5}$ pada khususnya tidak dapat terlindungi. Selain itu, mereka juga berpendapat bahwa pengaturan Pasal 2 Ayat (1) UU Perkawinan telah menghilangkan HAM dan hak konstitusional seluruh warga negara Indonesia.

Bertitik tolak dari penjelasan di atas, telah menunjukkan adanya kesenjangan antara hukum yang dicita-citakan (das sollen) dan realitas hukum yang ada di masyarakat tentang permasalahan hukum nikah beda (das sein). Menurut dasar hukum perkawinan Islam menentukan bahwa pernikahan beda agama tidak disahkan karena tidak memenuhi syarat, yakni salah satu calon pengantinnya tidak beragama Islam. Namun di masyarakat telah terjadi pengabaian hukum agama, bahkan ada gagasan untuk memisahkan antara hukum perkawinan dengan aturan agama. Oleh karena itu, sangat perlu diadakan penelitian tentang "Analisis Yuridis Pernikahan Beda Agama Menurut Hukum Islam Di Indonesia".

Berdasarkan uraian di atas, maka permasalahan dalam penelitian ini dapat dirumuskan sebagai berikut:

a. Bagaimanakah analisis yuridis pernikahan beda agama menurut Hukum Islam di Indonesia?.

b. Bagaimanakah akibat hukum pernikahan beda agama menurut Hukum Islam di Indonesia ?

\section{Metode Penelitian}

Jenis penelitian ini adalah penelitan normatif atau doktrinal yang bertujuan untuk menganalisis aturan yuridis tentang nikah beda agama yakni UU Perkawinan No. 1 Tahun 1974 Pasal 2 Ayat 1 dan Pasal 8 Huruf (f), KHI Inpres No. 1/1991 Pasal 40 Poin (c), 44 dan 118, dan Pasal 44, Fatwa MUI dalam Musyawarah Nasional ke II pada tanggal 26 Mei-1 Juni 1980, Fatwa FPI, Keputusan Majlis Tarjih Muhammadiyah ke-22 di Jawa Timur, Keputusan Bahstul Masail NU. Penelitian ini termasuk jenis penelitian kualitatif yang bertujuan untuk membangun konsep teori yang berdasarkan bahan bacaan.

Metode pendekatannya dengan menggunakan pendekatan juridis doctrinal. Yuridis artinya penelitian yang berusaha meneliti hal-hal yang menyangkut hukum, baik formil mapun informil. Doktrinal adalah penelitian yang berusaha meneliti tentang aturan yuridis nikah beda agama dan akibat hukumnya. Data penelitian yang dibutuhkan adalah sumber data sekunder di bidang

\footnotetext{
3. Abdul Halim, Carina Rizky Ardhani, "Keabsahan Perkawinan Beda Agama Diluar Negeri Dalam Tinjauan Yuridis", Jurnal Moral Kemasyarakatan, Vol. 1, No.1, Juni 2016, E-ISSN 2527-4, Program Studi Pendidikan Pancasila Dan Kewarganegaraan Universitas Kanjuruhan Malang dan Asosiasi Profesi Pendidikan Pancasila dan Kewarganegaraan Indonesia (AP3KnI), Jawa Timur, hlm. 4.

4. Novina Eky Diyanti, "Perkawinan Beda Agama Antar Warga Negara Indonesia Di Luar Negeri Sebagai Bentuk Penyelundupan Hukum Dari UU No. 1/1974 Tentang Perkawinan”, Jurnal Privat Law FH UNS, Vol. II, No. 5, JuliOktober 2014, hlm. 6.

5. Ibid, hlm. 7

6. Muhammad Daud Ali, 1997, Hukum Islam dan Peradilan Agama, Jakarta, Raja Grafindo, hlm. 57-58.
} 
hukum, yang dibedakan menjadi bahan hukum primer, sekunder dan tersier. Metode pengumpulan data melalui metode dokumentasi dan data penelitian akan dianalisis secara kualitatif, logika hukum induktif, interpretasi/ penafsiran hukum, deskriptifanalitis. Pengolahan data dilakukan dengan cara menelaah, mengorganisir, menkonsep atau menyusun data, mensintesa, menganalisa, mengedit (editing), coding dan menyimpulkan.

\section{Kerangka Teori}

Perkawinan merupakan akad (perjanjian) yang luar biasa dibandingkan dengan akad-akad lain. Oleh karena itu memerlukan keinginan beriktikad baik guna menjalin hubungan harmonis antara suamiisteri sebagai pelaku perkawinan, sehingga tujuan perkawinan bisa tercapai, yakni mendapatkan keturunan yang sah, membentuk keluarga yang bahagia, memenuhi kebutuhan batin, membentuk ketenangan hati, dan dapat mengekspresikan kasih sayang. ${ }^{7}$

Dasar hukum perkawinan Islam bersumber dari Al-Qur'an, Al-Hadist dan kitab-kitab fiqh tentang pernikahan (fiqh munakahat). Oleh pemerintah dasar hukum perkawinan tersebut telah diatur dalam bentuk peraturan perundang-undangan dan himpunan kitab hukum, uraian selengkapnya akan dijelaskan melalui Tabel 1.8

Tabel 1. Dasar Hukum Perkawinan di Indonesia

\begin{tabular}{|c|l|l|}
\hline No. & \multicolumn{1}{|c|}{$\begin{array}{c}\text { Peraturan Tentang } \\
\text { Perkawinan }\end{array}$} & \multicolumn{1}{|c|}{ Materi } \\
\hline 1. & No. 22 Tahun 1946 & $\begin{array}{l}\text { Pencatatan Nikah, Talak, Cerai dan } \\
\text { Rujuk }\end{array}$ \\
\hline 2. & UU No. 32 Tahun 1954 & $\begin{array}{l}\text { Penetapan berlakunya UU RI No. 22 } \\
\text { Tahun 1946 tentang Pencatatan Nikah, } \\
\text { Talak, Cerai dan Rujuk di seluruh Jawa } \\
\text { dan Madura }\end{array}$ \\
\hline 3. & UU No. 1 Tahun 1974 & $\begin{array}{l}\text { Perkawinan dan sedikit disinggung } \\
\text { acaranya. }\end{array}$ \\
\hline 4. & PP No. 9 Tahun 1975 & Pelaksanaan UUP No.1/1974 \\
\hline 5. & UU No. 7 Tahun 1989 & Peradilan Agama \\
\hline 6. & UU No. 3 Tahun 2006 & $\begin{array}{l}\text { Penyempurnaan Peradilan } \\
\text { tentang kewenangan absolutnya (Pasal } \\
\text { 49) }\end{array}$ \\
\hline 7. & $\begin{array}{l}\text { KHI Instruksi Presiden No. 1 } \\
\text { Tahun 1991 }\end{array}$ & Buku I tentang Perkawinan \\
\hline
\end{tabular}

Merujuk pada Tabel 1, maka dapat diketahui bahwa rukun dan syarat adalah hal yang menentukan sah atau tidaknya pernikahan dari segi hukum. Pernikahan yang tidak memenuhi rukun dan syaratnya berarti tidak sah dan batal demi hukum. Syarat perkawinan ada dua macam, yakni syarat umum dan syarat khusus. Syarat umum adalah syarat yang berdiri sendiri dan tidak berkaitan dengan unsur-unsur rukun, sedangkan syarat khusus artinya syarat yang berlaku bagi tiap rukun perkawinan. Syarat perkawinan khusus mengikuti rukunnya, antara lain : ${ }^{9}$

a. Calon mempelai pria, syaratnya adalah; beragama Islam, laki-laki, jelas orangnya, cakap hukum, dewasa, tidak terdapat halangan pernikahan, berakal (sehat jasmani dan rohani).

b. Calon mempelai wanita, syaratnya adalah; beragama Islam, perempuan, jelas orangnya, cakap hukum, dewasa, berakal (sehat jasmani dan rohani), tidak terdapat halangan perkawinan

c. Wali nikah, syaratnya adalah; laki-laki, dewasa, mempunyai hak perwalian,

\footnotetext{
7. Amir Syarifuddin, 2006, Hukum Perkawinan Islam di Indonesia, Antara Fiqh Munakahat Dan Undang-Undang Perkawinan, Jakarta, Prenada Media, hlm. 46-47.

8 Ibid, hlm 20-21.

9. Mardani, 2011, Hukum Perkawinan Islam di Dunia Islam Modern, Yogyakarta, Graha Ilmu, hlm. 10.
} 
tidak terdapat halangan perwalian, Islam, dan sehat jasmani serta rohani.

d. Saksi nikah, syaratnya adalah; minimal dua orang laki-laki, hadir dalam ijab dan qabul, dapat mengerti maksud akad, tidak cacat rohani, Islam, dan dewasa.

e. Akad, ijab dan Qabul, syaratnya; adalah adanya pernyataan mengawinkan dari wali, adanya pernyataan penerimaan dari calon mempelai pria, memakai kata-kata nikah atau tazwij atau terjemahnya, antara ijab dan qobul bersambungan, antara ijab dan qobul jelas maksudnya, yang terikad ijab dan qobul tidak sedang ikhram, dan majlis ijab qabul minimal dihadiri empat orang.

Kaitannya dengan nikah beda agama, menurut hukum agama (Islam) menjelaskan bahwa nikah tersebut termasuk nikah fasid atau nikah yang cacat hukum, karena kedua pasangan tersebut tidak memenuhi syarat perkawinan yakni beragama Islam. Pelarangan nikah beda agama menurut ajaran agama yang diakui di Indonesia (Islam, Kristen, Katolik, Hindu, Budha, Kong Huchu) tidak diperbolehkan atau tidak dianjurkan atau tidak sah. ${ }^{10}$ Hal ini disebabkan karena masing-masing agama mengajarkan supaya umatnya menikah dengan pasangan yang satu akidah atau keimanan.

Nikah beda agama menurut hukum Islam dapat dilakukan, apabila salah satu pasangan bersedia pindah agamanya supaya pernikahan terpenuhi rukun dan syaratnya, sehingga hukumnya sah dan dapat dicatatkan oleh negara. ${ }^{11}$ Bagi mereka yang melangsungkan pernikahan menurut agama Islam, maka pernikahannya dicatatkan di KUA. Sedangkan bagi mereka yang melangsungkan pernikahan menurut agama non Islam, maka dicatatkan di KCS (Kantor Catatan Sipil).

\section{B. Hasil dan Pembahasan}

1. Analisis Yuridis Nikah Beda Agama Menurut Hukum Islam di Indonesia Analisis vuridis pernikahan beda agama

10. Muhammad Daud Ali, Op. cit, hlm. 71

11. Ibid, hlm. 60

12.Muhammad Anshary, 2010, Hukum Perkawinan Di Indonesia (Masalah-Masalah Krusial), Yogyakarta, Pustaka Pelajar, hlm. 49-51. menurut hukum Islam di Indonesia berarti menjelaskan tentang dasar hukum nikah beda agama menurut perundang-undangan, kemudian dianalisis menurut hukum Islam. Menurut sejarah hukum keluarga di Indonesia, pada awalnya perkawinan beda agama disebut dengan istilah perkawinan campuran, landasan hukumnya terdapat pada ketentuan Pasal 1 GHR (Regeling of de Gemengde Huwalijen Staatsblaad 1898 No. 158) yang menjelaskan bahwa perkawinan campuran adalah perkawinan antar orangorang yang di Indonesia tunduk pada hukum yang berlainan, termasuk nikah beda agama karena berlainan agama (interreligeus). Juga terdapat dalam Pasal 7 Ayat (2) GHR yang menjelaskan bahwa perbedaan agama, bangsa atau asal sama sekali bukan menjadi penghalang perkawinan.

Namun setelah lahirnya UU Perkawinan No. 1/1974, perkawinan campuran mengalami perubahan arti, karena menurut Pasal 57 UU Perkawinan No. 1/1974 menjelaskan bahwa :

"Perkawinan campuran adalah perkawinan antara dua orang yang di Indonesia tunduk pada hukum yang berlainan, karena perbedaan kewarganegaraan dan salah satu pihak berkewarganegaraan Indonesia”.

Berdasarkan bunyi pasal di atas, dapat dipahami bahwa perkawinan campuran menurut UU Perkawinan menunjuk pada perbedaan kewarganegaraan Indonesia dengan kewarganegaraan asing, bukan perbedaan agama. Hal ini berakibat bahwa sejak keluarnya UU Perkawinan No. 1/1974, aturan tentang dibolehkannya nikah beda agama menurut GHR Pasal 1 dan Pasal 7 Ayat (2) dinyatakan tidak berlaku. Pemberlakuan nikah beda agama selanjutnya terdapat dalam hukum agama masing-masing, sebagaimana dijelaskan dalam UUP No.1/1974 Pasal 2 Ayat (1) menjelaskan bahwa "perkawinan adalah sah, apabila dilakukan menurut hukum masing-masing agamanya dan kepercayaannya itu".

Walaupun persoalan pernikahan beda agama dalam UUP tersebut tidak dijelaskan secara tekstual. Namun, apabila dipahami 
pasal tersebut menjelaskan bahwa peran hukum agama berkedudukan sebagai parameter atau tolak ukur tentang sahnya pernikahan, sehingga penentuan boleh tidaknya perkawinan tergantung dari hukum agama. Apabila dalam hukum agama menyatakan sahnya suatu perkawinan, maka sah juga menurut hukum negara.

Hukum Islam yang mengatur pernikahan untuk orang Islam telah mengatur aturan tentang nikah beda agama, yakni:

a. Keputusan Majlis Tarjih Muhammadiyah ke 22 tahun 1989 di Malang Jawa Timur menjelaskan bahwa menurut hukum agama Islam, pernihakan wanita non muslim dengan laki-laki muslim adalah haram. Hal ini mengandung arti bahwa pernikahan beda agama, dalam segala bentuknya tidak diperbolehkan. ${ }^{13}$

b. Pasal 40 Poin (c) dan Pasal 44 KHI Inpres No. 1/1991, menamakan perkawinan beda agama dengan sebutan perkawinan antar pemeluk agama. Pada Pasal 40 poin (c) KHI menyatakan bahwa dilarang melangsungkan pernikahan antara seorang pria dengan seorang wanita yang tidak beragama Islam. Kemudian dalam Pasal 44 menyatakan bahwa wanita Islam dilarang melangsungkan perkawinan dengan seorang pria yang tidak beragama Islam. Berdasarkan ketentuan Pasal 40 poin (c) dan $44 \mathrm{KHI}$ di atas memahamkan bahwa garis hukum pernikahan beda agama menurut hukum perkawinan Islam adalah tidak boleh. Bagi orang Islam tidak ada kemungkinan untuk menikah dengan melanggar ketentuan agamanya. c. Munculnya permasalahan hukum tentang nikah beda agama, menurut UU Perkawinan No. 1 Tahun 1974 ternyata telah dijelaskan dalam Pasal 8 huruf(f), rumusannya adalah "perkawinan dilarang antara dua orang yang mempunyai hubungan yang oleh agamanya atau peraturan yang berlaku dilarang kawin". Jadi, menurut UU Perkawinan menjelaskan bahwa pernikahan beda agama termasuk pernikahan yang dilarang. ${ }^{14}$

d. Pasal 118 KHI yang menjelaskan bahwa murtad dapat digunakan sebagai alasan perceraian, adanya murtad mesti disebabkan oleh nikah beda agama. Para perumus KHI, yang berkedudukan sebagai mujtahid berpendapat bahwa penetapan dilarangnya nikah beda bertujuan untuk membentuk kemashlahatan, demi mempertahankan agama. Mereka lebih memprioritaskan kepentingan agama daripada kenikmatan jiwa manusianya dan menempatkan pemeliharaan kepentingan agama sebagai hak yang tidak dapat dikurangi dalam keadaan apapun. ${ }^{15}$

Pasangan yang menikah satu keimanan atau satu agama, maka rumah tangganya akan dilindungi oleh aturan yang seragam yang menjadi prinsip dasar dalam melaksanakan hak dan kewajiban masing-masing pasangannya. Mereka akan bersama-sama mengembangkan iktikad baiknya dalam menempuh tujuan perkawinan, mengelola harta kekayaan, mendidik anak dan menyelesaikan sengketa hukum. ${ }^{16}$

Nikah beda agama, menurut hukum Islam tidak diperbolehkan karena menyangkut

13.Pimpinan Wilayah Muhammadiyah Jawa Tengah, Dokumen Himpunan Putusan Majlis Tarjih Muhammadiyah 22 di Malang Jawa Timur, hlm. 8.

14. Ibid, hlm. 32

15. Faiq Thobroni, "Kawin Beda Agama Dalam Legeslasi Hukum Perkawinan Indonesia Perspektif HAM", Al-Mawardi Journal Islamic Law, Vol. XI, No. 2, September- Januari 2011, (Printed ISSN No. 0854-7408, Online ISSN No. ISSN: 2460-0342), the Department of Shari'ah the Faculty of Islamic Studies Islamic University of Indonesia Yogyakarta Indonesia in cooperation with the Association of Shari'ah Scientists and Scholars of Indonesia ( HISSYI - Himpunan Ilmuan dan Sarjana Syari'ah Indonesia ), Yogyakarta, hlm. 169.

16. Nancy J. Smith-Hefner, "The New Muslim Romance: Changing Patterns of Courtship and Marriage Among Educated Javanese Youth”, Journal of Southeast Asian Studies, Vol. 36, Issue 03, October 2005, pp 441 - 459, DOI: 10.1017/S002246340500024X, Printed in the United Kingdom, The National University of Singapore Published online: 08 September 2005, hlm. 18. 
perbedaan keimanan. Salah satu dasarnya adalah Fatwa MUI dalam Musyawarah Nasional ke II pada tanggal 26 Mei-1 Juni 1980 yang menetapkan bahwa nikah beda agama hukumnya haram, alasannya ${ }^{17}$ adalah:

a. Al-Qur'an Surat Al-Baqarah Ayat 221 menjelaskan bahwa diharamkan lakilaki muslim menikah dengan wanita tidak muslim sehingga mereka beriman. Selain itu juga menjelaskan bahwa diharamkan bagi wali menikahkan wanita yang berada di bawah tanggung jawabnya dengan laki-laki non Islam.

b. Al-Qur'an Surat Al-Mumtahanah Ayat 10 menjelaskan, supaya laki-laki beriman tidak mempertahankan perkawinannya dengan wanita non Islam, begitu juga wanita non muslim supaya dikembalikan kepada laki-laki muslim, karena perkawinan mereka diharamkan oleh Allah.

c. Al-Qur'an Surat Al-Tahrim ayat 6, memerintahkan supaya orang-orang beriman menjaga dan memelihara diri sendiri dan keluarganya dari api neraka.

d. Sabda Nabi Muhammad SAW yang diriwayatkan oleh Imam Al-Thabrani yang mengajarkan bahwa nikah itu setengah dari ajaran agama, dan kita diperintahkan untuk hati-hati terhadap sisanya.

e. Sabda Nabi Muhammad SAW yang diriwayatkan oleh Ibn Al-Sura'i yang mengajarkan tentang pentingnya pengajaran pendidikan agama bagi orang tua kepada anaknya, karena orang tualah yang menjadikan anaknya Yahudi, Majusi, Nasrani dan Islam.

Berdasarkan penjelasan dari alasan

hukum di atas dapat dipahami bahwa :

a. Nikah beda agama dalam segala bentuknya dilarang;

b. Wali perempuan (ayah, kakek, dan saudara dari kerabat laki-laki) dilarang menikahkan anak perempuannya dengan laki-laki non muslim;

c. Wali perempuan (ayah, kakek, dan saudara dari kerabat laki-laki) dilarang mempertahankan perkawinan beda agama anak perempuannya dengan laki- laki non muslim, karena hubungan batin pasangan tersebut menurut hukum Islam termasuk perbuatan zina, sebab perkawinannya sudah tidak sah lagi;

d. Bagi umat Islam, dianjurkan tidak melakukan nikah beda agama, apabila melakukan nikah beda agama hendaknya sesuai dengan hukum Islam demi menjaga dan menyelamatkan diri dan keluarganya dari api neraka;

e. Para orang tua hendaknya mengajarkan kepada anaknya supaya mempunyai keimanan dan ketaqwaan kepada Allah SWT, sehingga tidak melakukan nikah beda agama yang melanggar ketentuan Islam.

Berdasarkan penjelasan di atas, dapat dipahami bahwa dasar hukum nikah beda agama berasal dari hukum agama yang dianut di Indonesia. Pemberlakuan hukum agama dalam perkawinan, apabila dikaji, sesuai dengan landasan idiil Pancasila sila pertama Pancasila, yakni " Ketuhanan Yang Maha Maha Esa". Sila ini menjelaskan bahwa segala aturan hukum, termasuk hukum perkawinan harus sesuai dengan ajaran Tuhan Yang Maha Esa, artinya tidak boleh bertentangan dengan moral agama yang hidup di Indonesia. ${ }^{18}$ Selain itu juga berdasarkan landasan konstitusionil UUD 1945, Pasal 29 Ayat (1) dan (2) yang menyatakan adanya jaminan perlindungan hukum bagi warga negara untuk melaksanakan ajaran agama termasuk hukum perkawinan sesuai ajaran agama yang diyakininya, sehingga pengembangan kehidupan beragama dapat menyuburkan nilai-nilai etika dan moral di masyarakat. ${ }^{19}$

Pemberlakuan hukum nikah beda agama juga sesuai dengan putusan MK No. 68/PUU/XII/2014 yang menguatkan hukum agama untuk menjadi barometer dalam menentukan sah atau tidaknya perkawinan, termasuk tidak sahnya pernikahan beda agama karena melanggar konstitusi negara. Selain itu, putusan MK No. 68/PUU/XII/2014 telah mengarahkan dan memberikan petunjuk tentang penafsiran Pasal 1 Ayat (2) UUP

17. Jaih Mubarok, 2015, Pembaharuan Hukum Perkawinan di Indonesia, Bandung, Simbiosa Rekatama Media, hlm.

18. 119.

Ibid. 
secara benar, adil dan sesuai dengan ilmu hukum tentang bagaimana membaca, memahami dan menafsirkan pasal dan ayat dalam suatu perundang-undangan. ${ }^{20}$

\section{Akibat Hukum Nikah Beda Agama Menurut Hukum Islam di Indonesia}

Nikah beda agama merupakan perbuatan yang melanggar hukum, karena semua agama mengajarkan pada umatnya supaya menikah yang satu keimanan. Nikah beda agama akan berakibat kompleks pada beberapa hal, antara lain :

a. Hukum perkawinan di Indonesia tidak berlaku efektif, akan menjadi kaidah yang mati, karena tidak ditaati masyarakat.

b. Merusak mentalitas muslim, karena tidak konsekuen terhadap hukum agamanya. Hal ini termasuk perbuatan menyeleweng dari ajaran prinsip tauhid.

c. Berpengaruh pada pola pendidikan anak, perbuatan nikah beda agama akan berakibat pada 3 pola pendidikan anak, yakni; anak dididik mengikuti agama pasangan yang beragama Islam, anak dididik mengikuti agama pasangan non Islam, dan anak tidak dididik ajaran agama. Kewajiban dasar orang tua kepada anak adalah mendidik dan membimbing anak untuk tidak menyekutukan Allah dan menjadi anak sholeh dan sholekhah. ${ }^{21}$

d. Berpengaruh pada hukum waris mewarisi antara pewaris dan ahli waris. Apabila terjadi nikah beda agama antara anak dan orang tua sebagai pewaris atau ahli waris, maka keduanya tidak berlaku hukum waris mewarisi karena tidak memenuhi syarat hukum waris Islam. Jadi, ahli waris yang beda agama ketika pewaris meninggal dunia, maka akan menjadi penghalang ahli waris tersebut untuk menerima harta warisan. Dasar hukumnya adalah Hadist riwayat Bukhari dan Muslim yang artinya "Orang Islam tidak berhak mewarisi harta orang kafir, dan orang kafir tidak berhak mewarisi harta orang Islam" ( HR. Bukhari dan Muslim). Juga terdapat dalam Hadist yang diriwayatkan oleh Ashhab al-Sunan yang artinya "Tidak dapat saling mewarisi antara dua orangg pemeluk agama yang berbeda" (HR. Ashhab AlSunan).

e. Berpengaruh pada hukum perkawinan Islam, pada masalah wali nikah dari mempelai perempuan. Wali mempunyai kewajiban untuk menikahkan anak perempuannya kepada laki-laki yang dikendakinya. Salah satu syarat wali adalah beragama Islam, apabila terjadi perbedaan agama antara anak perempuan dan walinya, tentunya menjadi penghalang untuk melangsungkan pernikahannya.

f. Berpengaruh pada hukum perkawinan pada hak asuh anak (hadhanah) ketika orang tua bercerai. Apabila terjadi perceraian dan usia anak di bawah 12 tahun, maka hak asuh anaknya ada di tangan ibunya, sedangkan biaya nafkah, pendidikan dan kesehatan ada di tangan ayahnya, semua itu dilakukan karena kepentingan anak. Namun, apabila ibunya tidak muslim, maka tidak berhak hadhanah karena kekafirannya. Sebab hak hadhanah meliputi pendidikan agama pada anak tersebut.

Akibat hukum nikah beda agama adalah perkawinan menjadi batal setelah ada keputusan pengadilan yang mempunyai kekuatan hukum tetap. Apabila tidak ada pihak yang mengajukan permohonan pembatalan pernikahan, maka menurut hukum positif di Indonesia, baik UUP maupun KHI, menghukumi bahwa pernikahan sah dilakukan. Menurut hukum Islam normatif yakni hukum Islam yang berdasarkan wahyu Allah yakni Al-Qur'an, Al-Hadist dan beberapa kitab fiqh menjelaskan bahwa perkawinan tersebut di mata Allah telah rusak dan pelakunya

20. Islamiyati, "Implikasi Yuridis Putusan Mahkamah Konstitusi No.68/PUU/XII/2014 Terhadap Penyelundupan Hukum Nikah Beda Agama dalam Perspektif Hukum Islam”, Tesis, MIH UNDIP, Semarang, 2016, hlm. 234.

21. LihatAl-Qur'an Surat Luqman Ayat 12-19.

22. Ahmad Azhar Basyir, 2009, Hukum Waris Islam, Yogyakarta, UII Press, hlm. 94. 
dianggap berbuat zina karena melakukan perkawinan yang tidak sah sebab tidak terpenuhi syaratnya, yakni calon suami dan isteri harus beragama Islam. Akibat hukumnya adalah nikah tersebut tidak sah dan batal demi hukum. Walaupun tidak ada pengajuan permohonan pembatalan, namun nikah tersebut batal di mata Allah dan sanksi akhirat atau perasaan berdosa niscaya telah menjadikannya sebagai peringatan akan perbuatannya. Berdasarkan penjelasan tersebut dapat dipahami, bahwa sanksi pelanggaran hukum nikah beda agama ada dua, yakni sanksi dari Allah dan sanksi dari manusia melalui hukum perkawinan di Indonsia.

\section{Simpulan}

Berdasarkan uraian di atas, dapat disimpulkan bahwa :

1. Nikah beda agama menurut aturan yuridis di Indonesia yakni yakni UU Perkawinan No. 1/1974 Pasal 2 Ayat 1 dan Pasal 8 Huruf (f), KHI Inpres No. 1/1991 Pasal 40 Poin (c), 44 dan 118, dan Pasal 44, Fatwa MUI dalam Musyawarah Nasional ke II pada tanggal 26 Mei-1 Juni 1980, Fatwa FPI, Keputusan Majlis Tarjih Muhammadiyah ke-22 di Jawa Timur, Keputusan Bahstul Masail NU, menetapkan bahwa perkawinan beda agama dalam segala bentuknya tidak diperbolehkan, kecuali terjadi penyamaan akidah atau keimanan bagi pasangan. Setiap perkawinan dinyatakan sah jika mekanisme, tata cara, aturannya sesuai dengan norma dan aturan agama yang diyakini dan dipercayai setiap warga negara.

2. Akibat hukum pernikahan beda agama menurut hukum Islam positif adalah perkawinan menjadi batal apabila ada pihak yang mengajukan permohonan pembatalan pernikahan kepada hakim, dan keputusan hakim telah mempunyai kekuatan hukum tetap. Menurut hukum Islam normatif menjelaskan bahwa perkawinan tersebut di mata Allah telah rusak dan pelakunya dianggap berbuat zina karena melakukan perkawinan yang tidak sah sebab tidak terpenuhi syaratnya.

Alasannya karena akan terjadi benturan hukum pada masalah intern perkawinan, hak waris mewarisi, hak wali nikah dalam perkawinan, dan hak asuh anak (hadhanah) ketika orang tua bercerai.

Saran yang layak disampaikan adalah supaya menjadi warga negara yang tidak melakukan nikah beda agama supaya konsekuen terhadap ajaran agamanya. Hal inilah yang menjadikan masyarakat tertip dan teratur, tidak melanggar hukum dan melahirkan sikap toleransi antar umat beragama.

\section{Daftar Pustaka}

Al-Qur'an Surat Luqman Ayat 12-19.

Azhar Basyir Ahmad, 2009, Hukum Waris Islam, Yogyakarta, UII Press.

Daud Ali Muhammad, 1997, Hukum Islam dan Peradilan Agama, Jakarta, Raja Grafindo.

Syarifuddin Amir, 2006, Hukum Perkawinan Islam di Indonesia, Antara Fiqh Munakahat Dan Undang-Undang Perkawinan, Jakarta, Prenada Media.

Departemen Agama RI, 2004, UndangUndang Nomor 1 Tahun 1974 Tentang Perkawinan dan Peraturan Pemerintah Nomor 9, Tahun 1975, Serta Kompilasi Hukum Islam di Indonesia, Jakarta, Departemen Agama R.I. Derektorat Jenderal Bimbingan Masyarakat Islam dan Penyelenggaraan Haji.

Eky Diyanti Novina, "Perkawinan Beda Agama Antar Warga Negara Indonesia Di Luar Negeri Sebagai Bentuk Penyelundupan Hukum Dari UU No. 1/1974 Tentang Perkawinan", Jurnal Privat Law FH UNS, Vol. II, No. 5, Juli-Oktober 2014.

Halim Abdul, Carina Rizky Ardhani, "Keabsahan Perkawinan Beda Agama Diluar Negeri Dalam Tinjauan Yuridis", Jurnal Moral Kemasyarakatan, Vol. 1, No.1, Juni 2016, E-ISSN 2527-4, Program Studi Pendidikan Pancasila Dan Kewarganegaraan Universitas Kanjuruhan Malang dan Asosiasi 
Profesi Pendidikan Pancasila dan Kewarganegaraan Indonesia (AP3KnI), Jawa Timur.

Islamiyati, "Implikasi Yuridis Putusan $\mathrm{M}$ a h k a m a h Kons t it u s i No.68/PUU/XII/2014 Terhadap Penyelundupan Hukum Nikah Beda Agama dalam Perspektif Hukum Islam ”, Tesis, MIH UNDIP, Semarang, 2016.

J. Smith-Hefner Nancy, "The New Muslim Romance: Changing Patterns of Courtship and Marriage Among Educated Javanese Youth", Journal of Southeast Asian Studies, Vol. 36, Issue 03, October 2005, pp 441 - 459, DOI: $10.1017 / \mathrm{S} 002246340500024 \mathrm{X}$, Printed in the United Kingdom, The National University of Singapore Published online: 08 September 2005.

Mardani, 2011, Hukum Perkawinan Islam di Dunia Islam Modern, Yogyakarta, Graha Ilmu.

Mubarok Jaih, 2015, Pembaharuan Hukum Perkawinan di Indonesia, Bandung, Simbiosa Rekatama Media.

Muhammad Anshary, 2010, Hukum Perkawinan Di Indonesia (MasalahMasalah Krusial), Yogyakarta, Pustaka Pelajar.

Muhammad Daud Ali, 1997, Hukum Islam dan Peradilan Agama, Jakarta, Raja Grafindo.

Pimpinan Wilayah Muhammadiyah Jawa Tengah, Dokumen Himpunan Putusan Majlis Tarjih Muhammadiyah 22 di Malang Jawa Timur.

Thobroni Faiq, "Kawin Beda Agama Dalam Legeslasi Hukum Perkawinan Indonesia Perspektif HAM", AlMawardi Journal Islamic Law, Vol. XI, No. 2, September- Januari 2011, (Printed ISSN No. 0854-7408, Online ISSN No. ISSN: 2460-0342), the Department of Shari'ah the Faculty of Islamic Studies Islamic University of Indonesia Yogyakarta Indonesia in cooperation with the Association of Shari'ah Scientists and Scholars of Indonesia (HISSYI - Himpunan Ilmuan dan Sarjana Syari'ah Indonesia), Yogyakarta.
UUD NRI 1945 (kaidah dasarnya).

UU Nomor 1 Tahun 1974 tentang Perkawinan.

Kompilasi Hukum Islam berdasarkan Inpres Nomor 1 Tahun 1991. 